\title{
Персоналии
}

\section{БАЗАРНОВА НАТАЛЬЯ ГРИГОРЬЕВНА}

Наталья Григорьевна Базарнова - главный редактор научного журнала «Химия растительного сырья», доктор химических наук, профессор, декан химического факультета Алтайского государственного университета, заведующая кафедрой органической химии, 2 июля 2017 г. отмечает свой юбилей!

Становление научного работника и профессионального педагога началось с сельской средней школы, когда в 7 классе проявился первый интерес к химии, как только начали изучать этот предмет в школе. Это заслуга первого учителя химии, Нины Ожерельевой, которая вложила все знания и талант и увлекла органической химией, самой логичной областью химической науки, основой живых систем.

Далее - обучение на химическом факультете только что организованного Алтайского государственного университета. В процессе обучения студенты химического факультета активно занимались научной работой. Для Натальи Григорьевны научная работа в университете под руководством А.И. Галочкина, канд. хим. наук, доцента, стала настоящей школой интеллектуального мастерства и предопределили

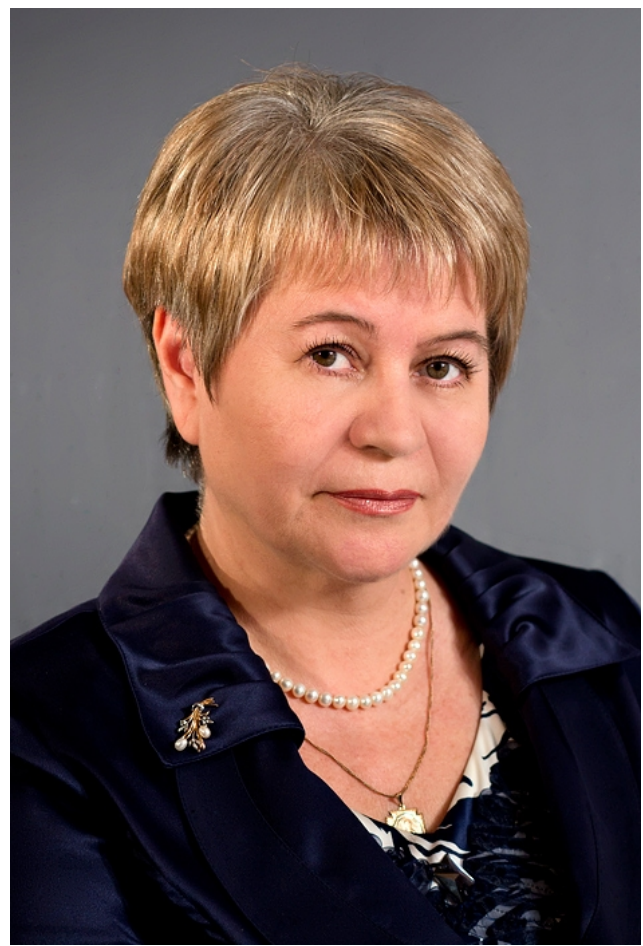
ее будущее.

Выпускница первого набора на химический факультет Алтайского государственного университета, который с успехом окончила и поступила в аспирантуру НГУ (1979 г.), параллельно совмещая с работой ст. лаборанта на кафедре органической химии АГУ. С 1983 г. она научный сотрудник, ассистент кафедры. В 1985 г. она первый выпускник ХФ АГУ, защитивший кандидатскую диссертацию (Институт химии древесины, Рига, ЛатвССР). С 1987 г. она старший преподаватель, а с 1992 по 2000 г. работает в должности доцента кафедры органической химии. В 1999 г. в Красноярске блестяще защитила диссертацию на соискание ученой степени доктора химических наук по теме «Химические превращения древесины в реакциях О-алкилирования и этерификации», в которой сформулировано новое научное направление в области химии древесины. В рамках этого направления кафедра органической химии работает вот уже более 30 лет.

С 11 ноября 1999 г. начинается новый этап деятельности Н.Г. Базарновой, как талантливого руководителя-управленца. Она была избрана на должность декана химического факультета, на которой работает по настоящее время. Началось «строительство» и внедрение новых направлений и специальностей на химическом факультете АГУ: в 2000 г. осуществлен первый набор студентов на специальность «Безопасность жизнедеятельности в техносфере», в 2002 и 2006 гг. открыты бакалавриат и магистратура по четырем направлениям подготовки «Химия».

В настоящее время на факультете ведется подготовка выпускников по двум специальностям и двум направлениям, обучается более 400 студентов. Н.Г. Базарнова проводит огромную профориентационную работу с абитуриентами химического факультета. Встречаясь лично с каждым потенциальным студентом 
факультета, она неустанно пропагандирует естественно-научное образование - как основу современного производства и инновационного развития страны.

В 2003 г. ей присвоено звание профессора по кафедре органической химии.

За время работы под руководством Н.Г. Базарновой подготовлено девять кандидатов наук, защищено более 120 дипломных работ и более 20 магистерских диссертаций. Проводятся совместная работа по подготовке кадров и совместные научные исследования с Новосибирским государственным университетом, Институтом химии твердого тела и механохимии СО РАН, Новосибирским институтом органической химии СО РАН, химическим факультетом Московского государственного университета и др.

В настоящее время входит в состав совета Д 212.253.01 (Сибирский государственный технологический университет) по специальности 05.21 .03 - «Технология и оборудование химической переработки биомассы дерева; химия древесины». Неоднократно выступала в качестве оппонента по докторским и кандидатским диссертациям.

На протяжении последних 20 лет Н.Г. Базарнова осуществляла научное руководство рядом исследовательских программ и грантов в рамках Российского фонда фундаментальных исследований, Министерства образования РФ, федеральной целевой программы «Интеграция». С 1997 г. на средства гранта РФФИ (руководитель Н.Г. Базарнова) открыт научный журнал «Химия растительного сырья», становление и организацию работы которого Н.Г. Базарнова активно проводила сначала в качестве заместителя главного редактора, a c 2002 г. - главного редактора журнала. Она соредактор тематического переводного номера Russian Journal of Bioorganic Chemistry и входит в состав редакционной коллегии научных изданий: «Журнал Сибирского федерального университета», «Бутлеровские сообщения».

Бессменный председатель программного комитета Всероссийской научной конференции «Новые достижения в химии и химической технологии растительного сырья», которая вот уже семь раз была успешно проведена в Барнауле в 2003-2017 гг.

Н.Г. Базарновой сформировано новое научное направление в области химии древесины - химическое модифицирование растительного сырья без предварительного разделения на отдельные компоненты в полимерные композиции, обладающие комплексом полезных свойств. В рамках работы в данном направлении ею опубликовано более 400 научных работ.

Более пяти лет Наталья Григорьевна ведет активное участие в новом направлении кафедры - биотехнологическом превращении растительного сырья совместно с учеными-вирусологами из ФБГУН «Государственный научный центр вирусологии и биотехнологии «Вектор»» (Кольцово). Работы ведутся над поиском противовирусных препаратов из лекарственного растительного сырья, а также поиском и разработкой новых инновационных сверхкритических технологий для внедрения их в производство фармацевтических препаратов совместно с ЗАО «Алтайвитамины».

Организационная, научная и учебная работа Н.Г. Базарновой неоднократно отмечалась почетными грамотами местного и федерального уровня. Ей присвоено звание «Почетный работник высшего профессионального образования». В 2007 г. Наталье Григорьевне была вручена губернатором Алтайского края А.Б. Карлиным медаль «За заслуги в труде».

Коллектив кафедры органической химии, химического факультета Алтайского государственного университета, члены редакционной коллегии журнала «Химия растительного сырья» сердечно поздравляют Наталью Григорьевну со знаменательной датой! Желаем здоровья, счастья и дальнейших творческих успехов!

Коллеги, ученики, редколлегия журнала «Химия растительного сырья» 